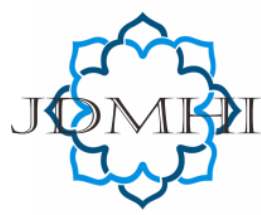

email: jdmhi@walisongo.ac.id

Journal of Digital Marketing and Halal Industry

ISSN: 2716-4810 (print) ISSN: 2716-4802 (online)

\title{
Utilization of Digital Marketing to Improve Sales Volume of MSME's Products
}

\section{Nafiudin Al-Bantani, Hamdan}

Fakultas Ekonomi dan Bisnis, Universitas Serang Raya, Banten Indonesia

\section{A R T I C L E I N F O}

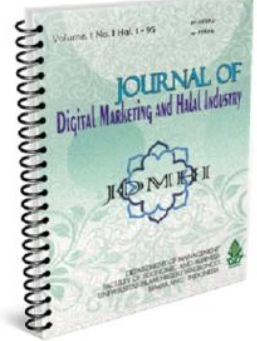

Article history:

Received 26 February 2020

Accepted 03 July 2020

Published 10 July 2020

Keywords:

Digital marketing, social Media, and Micro Small Medium

Enterprise.
A B S T R A C T

Micro, Small, Medium Enterprise (MSME's) marketing is still limited to traditional models and has not yet utilized digital marketing optimally. The purpose of this article is to identify the use of social media to increase the sales volume of MSME's products. This article uses the literature study method, using secondary data. Data analysis techniques used a descriptive approach. The results of studies and analysis show that the importance of using social media such as Collaborative projects (Example: Wikipedia), content communities or sharing media such as YouTube, social networking sites (example: Facebook), and virtual social worlds or market places such as open outlets, Tokopedia, and shopper. Optimizing social media can increase market share and sales of MSME's products.

@2020 Journal of Digital Marketing and Halal Industry

\section{Introduction}

The most common type of personal business in the City of Serang is the trade and services sector. The trade sector in terms of scale is generally divided into two, wholesale and retail trade. Retail trade products include cuisine (warteg/warnas), groceries, pulses and data packages, household furniture, vegetables, children's toys, drinking water refills and etc. (Department of Commerce, Industry and Cooperatives, MSME Serang City). In comparison, the service sector in Serang includes photocopy, makeup artist, laundry, taxi, sewing services, carfix, tourism (tour and travel), courses/tutoring subjects, t-shirt printing, photography, barbershop and salon, internet rental, etc.

\footnotetext{
* Corresponding author. email: nafiuddin08@gmail.com DOI: http://dx.doi.org/10.21580/jdmhi.2020.2.1.5282
} 
Serang is now known as a city of emping chips production. Emping is one of the superior potential traded by MSMEs in Serang City because the raw material used is one hundred percent comes from the region of Banten. Emping is famous chips made by melinjo in Serang. There are two kinds of Emping chips, ceplis and raw. It named Cemplis chips because they are made from melinjo, which is usually given a spice or a different taste, such as the taste of onions, spicy flavor, and some are even given the taste of shrimp. While raw chips made from melinjo leather that is still raw. The second leading potential product of Serang City is Sate Bandeng. The special taste of Sate Bandeng is very popular in Serang and any other city such as Tangerang, Bogor, Cilegon and Jakarta.

Although Serang has products that have the potential to be liked by many people, the fact is not that relevant. MSMEs have not been able to develop their businesses; we can see it from its stagnant scale of sales volume. This is due to limited access to marketing and business networks that are not extensive (Mubarok, 2019). MSMEs do marketing only in the traditional way that has been passed down for generations since ancient times. It is called word of mouth. MSMEs do not have the insight and understanding of information technology that can be used as a marketing media. MSMEs also do not have access to obtain various information about the marketing system and information on market developments that exist.

Along with the development of the industry that if businesses are not able to adapt to these developments will potentially lose the competition and lead to bankruptcy, therefore businesses must be able to adapt by utilizing information technology. It is digital marketing. Digital marketing makes it easy for business people to monitor and provide all the needs and desires of potential customers. On the other hand, potential customers can also search for and get product information just by exploring the virtual world. In other words, digital marketing can reach all people wherever they are without the limitations of space and time. One of the digital marketing tools is social media. Several studies have concluded that the use of social media can increase sales volume. Case studies on bag sales at bag craftsmen in Ciampea (Muniroh Leny, 2017), and digital marketing are seen as the best media of promotion in terms of its effectiveness and efficiency. They can increase sales volume significantly (Theresia Pradiani: 2017). Based on this background, the formulation of the problem in this study is how the effect of digital marketing on the sale volume of MSME products in Serang. And the purpose of this research is to know the effect of digital marketing on increasing sales of MSME products in Serang

\section{Literature Review}

Definition of marketing, according to (Kotler, 1997) is a social and managerial process in which individuals and groups get what they need and want by creating, offering, and exchanging products with other parties. The definition of Marketing according to Harper W (2000: 4) that Marketing is "A social process involving important activities that enable individuals and companies to get what they need and want through exchanges with other parties and to develop exchange relationships. "The definition of marketing 
mix according to (Swastha, 2002) that Marketing Mix is "a combination of four variables of activities that are the core of the company's marketing system, namely products, price structures, promotional activities, and distribution systems.

\section{Products}

The definition, according to (Kotler, 1997) that a product is anything that can be offered to a market to meet needs. Products marketed include physical goods, services, people, places, organizations, and ideas. Five levels of products planning an offer or product, marketers need to understand the five product levels, namely: 1 . The main product is the benefits actually needed or will be consumed by customers of each product. 2. Generic products are basic products that can fulfill the most basic product functions. 3. Product expectations are formal products offered with various attributes, and conditions are formally expected and agreed to buy. 4 . Complementary products, namely various products, attribute quipped or supplemented with various benefits and services so that they can provide additional satisfaction and can be distinguished from competing products. 5. Potential products are all additions kinds and changes that might be developed for a product in the future. Product attributes are product elements that are considered important by consumers and are used as the basis for purchasing decisions, and product attributes include brand, packaging, labeling, complementary services, and guarantee

2. Price
According to Swastha (2002: 147) the price is "the amount (plus a few items if possible) needed to get a combination of goods and their services".Price is the amount of money that must be paid by consumers to get a product. Price is the only element of the marketing mix that provides income or income for the company while the other three elements (products, places, promotions) cause costs. Unlike the product characteristics of distribution channels, these two things cannot be changed or adjusted easily and quickly, because they usually involve long-term decisions. The main determining factor in pricing is the company's marketing objectives. These objectives can be in the form of profit maximization, maintaining the survival of the company, adding a large market share, making leadership in terms of quality, overcoming competition, applicating social responsibility. One of the marketing mix components is the price. So prices need to be supported and coordinated with each other with other components of the marketing mix, namely promotion, products, and distribution. Cost is a factor that determines the minimum price that must be set so that the company does not experience losses. Thus, every company has to pay huge attention to cost structure aspects (variable and fixed), as well as other types of costs such as opportunity costs, controllable costs, pocket costs, incremental costs, and replacement costs.

3. Place

The definition, according to Kotler (2006: 63) Place is "The activities of companies that make products available to the target". A place is a distribution channel, a series of 
interdependent organizations that are visible to one another in the process of making products or services ready to be used or consumed. Location means it relates to where the company must be based and conduct operations. In this case, there are three types of interactions that affect the location, namely:

a. Consumers come to the company if the situation is like this, then the location becomes very important. Companies should choose a place close to consumers so that it is easy to reach. In other words, it must be strategic.

b. The company goes to the consumer is a location that is not too important, but what must be considered is the delivery of services must remain of quality.

c. Companies (service providers) and consumers do not meet directly are service providers, and consumers interact through certain means such as telephone, computer, or mail. In this case, the location becomes very insignificant as long as communication between the two parties can take place. Both the location and selected channels are very dependent on market criteria and the nature of the service itself. For example, in freight forwarding services, if the market wants fast and timely delivery and the nature of goods that are not durable, then the location chosen must be a strategy, and channel should direct sales to be controlled.

\section{Promotion}

No matter how good the quality of a product, how attractive as it looks or how big the benefits are, if no one knows about its existence, then it is impossible to buy the product. Consumers cannot recognize a product that is already good at a good price, so the product will not succeed in the market. Facilities and infrastructure needed effectively so that information about the presence of a product can reach the community or consumers. The effort to introduce the product to consumers is the beginning of promotional activities. Philip Kotler (1997, 142) defines promotion as an activity carried out by a company to communicate the benefits of its products and to convince consumers to buy. Julian Cummins $(1991,11)$ defines promotion as a series of techniques that are used to achieve sales or marketing goals by using cost-effectively, by adding value to products or services to intermediaries or direct users. Usually not limited in a certain period. The promotion mix is a company's total marketing communication program consisting of advertisements, personal sales, sales promotions, and public relations that the company uses to achieve its advertising and marketing objectives. According to Basu Swastha (1999), a mix of personal selling and other promotional tools, all of which are planned to achieve the sales program. The promotion mix consists of:

a. Advertising (advertising), namely all costs that must be spent by sponsors to make non-personal presentations and promotions in the form of ideas, goods, and services

b. Personal selling, namely personal presentations by company salespeople to make sales successful and build relationships with customers.

c. Sales promotion, namely short-term incentives to encourage the purchase or sale of a product or service. 
d. Public relations (public relations), which is building good relations with the related public to gain support, build a "corporate image" like. And deal with or get rid of gossip, stories, and events that can be harmful.

e. Direct marketing (direct marketing), namely direct communication with several targeted consumers to obtain direct responses with several target consumers to obtain direct responses by using letters, telephone, fax, email, etc. to communicate directly with certain consumers or businesses to receive an immediate response.

Digital marketing is a marketing practice that uses digital distribution channels to reach consumers in relevant, personal, and costeffective ways (Satyo, 2009). Marketing activities will be carried out intensively using computer media, both from product offering, payment, and delivery. In the context of marketing, the condition of the global crisis has made many organizations start thinking about and searching for savings methods.

It is not a secret that the organization's highest costs always come from marketing and labor costs (Sanjaya, 2009: 13). Therefore business organizations must be clever to see opportunities for effective marketing activities in the digital age at a cost that is cheap and effective.

According to (Fang, Chen Ling. Lie, 2006), emarketing is the marketing process to customers using web media of services and products. Promotion, Advertisements, Payments, and Transactions can be made through web pages. Users of Internet marketing can access information easily anywhere with a computer connected to the Internet.
Strauss \& Frost, 2012, p. 28) specifically emphasizes that e-marketing is a marketing activity carried out using Internet technology. Marketing activities, such as making, communicating, and offering products that can provide value to customers, clients, company partners, and the wider community.

According to Jagdish \& Sharma (2005, p612), e-marketing creates fundamental behavioral changes in business and consumers similar to those related to the introduction of cars and phones, which reduce the need for a channel approach. E-marketing uses the Internet as a platform that allows companies to adapt to customer needs, reduce transaction costs, and allow customers to move anytime and anywhere without worrying about place and time.

Based on the opinion of Mohammed et al. (2003) the influence of internet marketing on the company's marketing strategy, there are four ways, namely:

1. Increased segmentation with the internet market segmentation is getting wider, because of the increasingly broad marketing reach. The Internet does not limit the breadth of marketing reach because all consumers around the world can access it easily.

2. Develop strategies more quickly in cycle time with a faster and easier flow of time, and marketing strategies can also be more quickly developed.

3. Increased accountability of marketing efforts information that can be obtained quickly and easily can improve the company's strategy to be further improved. So marketing can be done more transparently.

4. We are increasing the integration of marketing strategies with operational 
business strategies. The integration of the company's marketing strategy and marketing strategy via the Internet will improve business strategies and operational strategies.

According to Strauss and Frost (2009), the seven stages in designing e-marketing are Situation Analysis, E-Marketing Strategic Planning, Objectives, E-Marketing Strategy EMarketing), Implementation Plan, Budget, Evaluation Plan. The detailed explanation is:

1. Situation analysis in the first phase is the beginning of a business concept by analyzing the strengths, opportunities, weaknesses, and threats for the company. In this section, the situation analysis used is the SWOT analysis. According to Rangkuti (2004), SWOT analysis is the systematic identification of various factors to formulate a company's strategy. This analysis is suggested on the logic that can maximize Strengths and Opportunities, but as a matter of course, we take Weaknesses and Threats. The strategic decision-making process is always related to the development of the company's mission, goals, strategies, and policies. Thus strategic planning (strategic planner) must analyze the factors of the company's strategy (strengths, weaknesses, opportunities, and threats) in the current conditions. This is called Situation Analysis. SWOT analysis compares the internal factors of Strengths and Weaknesses with external factors Opportunities and Threats faced by the business world.

2. E-marketing Strategic Planning (Emarketing Planning Strategy)

3. Objectives (Objectives) Objectives in emarketing include aspects of the task, quantity, and time. Task (what will be achieved). Measured quantity (how much). Time frame (when). Most e-marketing aims to achieve various objectives, such as the following: Increase market share. Increase the number of comments on a blog or website. Increase sales revenue. Reducing costs (eg, distribution or promotion costs). Achieve brand goals (such as mend when we come back)-increase database size. Achieve Customer Relationship Management (CRM) objectives (such as increasing customer satisfaction, frequency of purchases, or customer reference levels). Improve supply chain management (such as by increasing member coordination, adding partners, or optimizing inventory levels).

4. E-marketing Strategy E-marketing strategy includes a strategy regarding 4P and relationship management to achieve the objectives of the plan regarding Product, Price, Place, Distribution Channels, and Promotion.

5. Implementation plan at this stage, the company decides how to achieve its objectives through effective strategies and strategies. F. Pearimemihihab marketing (4 P), management strategies, and other strategies to achieve the objectives of the plan and then compile an implementation plan (Implementation Plan). The company also checks to ensure the right marketing organization at the venue (staff, departmental structure, application service providers, etc. outside the company). The Internet has changed the place of exchange from marketplaces (like face-to-face interactions) to marketspace (like screen-toface interactions). The main difference is that technological interfaces now mediate the nature of the exchange relationship. 
With the move from people-mediated to technology-mediated interfaces, there are some interface design considerations encountered.

According to Rayport and J.Jaworski. (2003), there are various elements in designing a website, namely context (the context of the site reflects the value of beauty and usability of the site), content (content is all digital objects contained in a web in the form of audio, video, image or text ), community (community is a bond of relationships that occur between fellow visitors or customers of a website because of the similarity of interests or hobbies), customization (customization is the ability of the site to modify itself in accordance with the wishes of its users), communication (communication between companies and customers, consisting from Broadcast Dimension, Interactive Dimension, and Hybrid Dimension), connection (the ability of a website to move from a webpage to another webpage or other website with onclick both text, images and other toolbars), and commerce (commerce is a feature of the customer interface which supports various aspects of the transaction trading and has dimensions such as registration, shopping cart, security, credit card approval, one click shopping, order through affiliates, configuration technology, order tracking, delivery options).

6. Budget, the key to strategic planning, is to identify the expected return on investment. During the implementation of the plan, the marketer will continue to monitor the actual revenue and costs to see the results that have been achieved. The Internet is one tool that can be used to monitor results because the technology records visitors every click. To get accountable budget information, calculations need to be made about revenue forecasts, intangible benefits, cost savings, and emarketing costs (marketing costs).

7. Evaluation Plan E-marketing planning is carried out. Its success depends on continuous evaluation. This type of evaluation depends on the purpose of the plan. To determine the marketing results, companies can use a balanced scorecard to measure the success of an internet marketing program and whether the internet marketing program is suitable according to the objectives of the company. Andreas Kaplan and Michael Haenlein define social media as "an internet-based application group that builds on the ideology and technology of Web 2.0, and which enables the creation and exchange of user-generated content" .4Social media is online media that supports social interaction. Social media uses web-based technology that turns communication into interactive dialogue. Some of the popular social media sites today include Blog, Twitter, Facebook, Instagram, Path, and Wikipedia. Van Dijk also explains another definition of social media. Social media is a media platform that focuses on the existence of users who facilitate them in their activities and collaborations. Therefore, social media can be seen as an online facilitator that strengthens the relationship between users as well as a social bond marketplace is an internetbased online media (web-based) place for conducting business activities and transactions between buyers and sellers. Buyers can find as many suppliers as possible with the desired criteria so that they get according to market prices. In 
contrast, suppliers/sellers can find out companies that need their products/services (Opiida, 2014). The marketplace is an E-Business model that deals with sellers and buyers. Market Place in Indonesia is one of the national economic driving forces in the context of facing the era of globalization. For this, the MarketPlace needs to be developed in an orderly, reasonable, and efficient manner.

Based on the background and theories that have been put forward, the authors formulate a hypothesis on whether there is an influence of the use of digital marketing technology on the sale of MSME products in Serang.

\section{The Method, Data, and Analysis}

This article uses a descriptive qualitative analysis design with literature study methods. A literature study is written by looking for theoretical references that are relevant to the case under study. This article was written based on previous studies that have been conducted sourced from relevant international and national journals. The data in this study used secondary data sourced from books, the Internet, and previous research reports. Data analysis techniques used a descriptive approach.

\section{Result and Discussion}

Consumer behavior began to shift, and consumers began to use the Internet for various purposes ranging from finding news and information, emails, various files, photos, listening to music, watching movies, and so on. This condition is accelerating with the emergence of various social media expressive sites such as Blogs, Facebook, YouTube, Flicker, Twitter, and so on. People are increasingly connected and the community is growing. They began to change the rules of the game and become influencers in their community. The members will listen more to suggestions from fellow communities than the characters and commercials. If, in the past, only figures or artists became influencers, now everyone can become influencers. The term consumer (passive) shifts to prosumer (active) (Situmorang, 2011: 222). Online shopping is a process where consumers directly buy goods or services from sellers in real-time, without direct intermediary services with sellers (http://wikipedia.org).

Online shopping is defined as the behavior of visiting online stores through internet media to search, bid, or view products to buy and obtain the product. Online shopping occurs when a customer chooses the Internet to transact because of many factors that motivate customers to buy. Shopping through the Internet offers unique advantages. Through shopping, via the Internet, a buyer can see in advance the goods and services he wants to spend via the web promoted by the seller. This shopping activity is a new form of communication that does not require direct face-to-face communication. But can be done separately from and to all over the world through the media of Notebooks, Computers, or Mobile phones that are connected with internet services. In the context of online stores, in general, internet users can be classified into three types of users; Nonpurchases, browsers, and Purchasers (Dejan, 2010). 
1. Non-Purchasers are internet users who have never made searches and purchases at online stores.

2. Browsers are internet users who only make purchases at these online stores.

3. Purchasers are people who have done searches and purchases at online stores.

Entrepreneurial technology is a vehicle that facilitates individuals, business organizations, regions, the State towards prosperity, and therefore it becomes intellectual satisfaction when we discuss it. By definition, entrepreneurial technology is an investment project by gathering special individuals and collecting heterogeneous assets associated with advances in science and technology to create corporate value. There are four dimensions to entrepreneurial technology: a) The final result. b) the target of the final result. c) The mechanism used to provide the final result. d) The interdependence of this mechanism with scientific and technological advances. Digital marketing is marketing using the application of digital technology. One form of digital marketing using electronic media or the Internet is internet marketing (e-marketing). EMarketing is a marketing process that uses electronic communication technology, especially the Internet. The role of digital marketing strategies can be important in following the development of digital technology and developing plans to attract consumers and direct it to the combination of electronic communication and traditional communication (Chaffey, D. Chadwick, F. Johnston, 2009). "Social Media, a formal definition of the term first requires drawing a line to two related concepts that are frequently named in conjunction with it: Web 2.0 and User Generated Content" (Kaplan, Andreas. Haenlein, 2010). This means that social media is an application that allows the exchange and creation of user-generated content using internet media and web 2.0.

The benefits of social media for marketing are an easy way to know more customers, and make more dean with them, not only that with social media we are able to find target consumers more effectively for example with demographic strategies such as targeting consumers based on age, location and so on like Facebook and Twitter these two examples have these devices. And with social media we are able to expand our target market and find new customers, one example is by utilizing \#hashtags related to business and then used to get suitable prospective customers, by following and Like or commenting posts so that they know the brands and products that will be offered to consumers. And consumers can provide feedback directly related to the business that we live so that we can know what exactly is needed by consumers. Still related to the benefits of social media about fan page on Facebook with fan page facilities consumers can directly send suggestions, criticisms, and messages about products, with social media we are able to develop target markets faster with competitors, increase website visitors and search engine rankings, help consumers be able to reach a business. There are several types of social media, according to (Kaplan, Andreas. Haenlein, 2010).

a. Collaborative projects

This social media allows users to collaborate in loading, editing, or correcting content. Example: Wikipedia online encyclopedia. Marketers can build connections with contributors to this service to present the right data and information when it comes to related brands, especially if the content is specific to the brand. 
b. Blogs

Blogs that represent the earliest forms of Social Media and Blogging are online business models that use content to educate and market products and services. Blogs tend to have two parts: They create content and update it constantly. They also allow users to get involved. Examples are WordPress and Blogger.

c. Content communities or media sharing

The main purpose of this media is to share content between media users. There is video content, for example, YouTube, slide share, for instance, PowerPoint presentations, and types of photos using Flickr media, and for text types, for example, bookcrossing. Businesses can use this type to share visually strong content, such as product photos, brand activities, to content such as infographics or videos.

d. Social networking sites

Social networking sites are applications that allow users to connect by creating personal profile information, inviting friends and colleagues to have access to these profiles, and sending emails and instant messages with each other.

e. Virtual social worlds

Virtual social worlds are applications that simulate real-life via the Internet. Virtual social worlds are sites that allow users to interact in three-dimensional platforms using avatars that are similar to real-lifeexamples of e-commerce: Tokedia, Bukalapak, and so on.

f. Virtual game worlds

The virtual world, which implies a 3D environment, where users can appear in the form of avatars desired and interact with others as in the real world. For example, online games social media is an effective business promotion tool because it can be accessed by anyone, so the promotion network can be wider.

Social media is an indispensable part of marketing for many companies and is one of the best ways to reach customers and clients. Social media such as blogs, Facebook, Twitter, and YouTube have a number of benefits for companies and are faster than conventional media such as print media and TV advertisements, brochures and leaflets of social media when combined with the use of communication tools such as mobile phones can be easily done by businesses reaching the final consumer as in the United States there are more than 70 million small businesses that use Facebook to increase their sales.

Mobile devices such as the iPhone allow users to stay connected, and two platforms dominate the largest global market share, namely Android (85\%) and iOS (Apple: 14\%). The growth of smartphone usage from 2009. 2016 for the United States is $55 \%$ and $44 \%$. The user community is more involved in the Internet because it has a mobile device. Because most people do not have a computer in addition to a mobile device to be commonplace. Therefore along with the growth of cellular users will lead to the potential use of the Internet and use the money to shop online.

Several studies that have been carried out both nationally and internationally prove that social media plays a role in increasing sales as research conducted by (Handaruwati, 2017) by utilizing social media that was not previously used because it is not yet familiar with being able to receive many orders, so that sales volume is increasing fast compared to sales the old way. Digital marketing is seen as the best 
medium as the most effective means of promotion (Pradiani Theresia, 2017).

Websites and social media applications. Likewise, digital technology is increasingly being implemented by companies to respond positively to customer needs apart from that it can drive sales and increase efficiency by reducing costs. Information quality can be transferred through digital technology (Watson, 2006) Organizations are very focused on using digital technology to improve the quality of the information provided to their customers (Foroudi, P., Jin, Z., Gupta, S., Melewar, TC and Foroudi, 2016). Therefore, businesses are able to utilize digital technology to cross information related to MSME products. Examples are usage (e.g., newsletters, webinars, podcasts, courses).

According to research conducted by (Trio Mohamad Febriyantoro, 2018) that all MSME practitioners state that the use of digital marketing provides benefits that they are able to interact and inform directly with consumers, MSME practitioners say that the use of digital marketing expands their market share, increasing consumer awareness because SMEs routinely update information about products every day and increase sales because some MSMEs also collaborate with several marketplaces such as Shopee and Tokopedia.

Based on the discussion above. So if we want to continue to develop and maintain relationships with customers, the first is that we must always be active and make sure that the content we put into social media is up-todate and fresh and make sure that we engage and interact with customers. Second, be honest and respect the rules in social media, never give misleading information because it will harm our company. Third, give interesting things, because no one wants boring conversation partners, so that what we need to do is listen to customers, find what makes them want to be heard, listen to what makes them interested and comfortable and develop content that is appropriate their desires. Fourth, be humble; we need to study the existence of social media because there are many out there who have preceded us in using these media, don't ever assume we are more proficient in using social media.

Fifth, Be unprofessional; avoid creating content that is too serious and formal. And no need to hire writers or content creators who require expensive fees and don't be afraid of making mistakes in content.

\section{Conclusion}

Based on the results of the literature study, it can be concluded that to increase sales of MSME products, and MSME practitioners can use digital marketing. Not only Facebook, Twitter, Instagram, but MSME practicioners can also cooperate with marketplaces such as Bukalapak, Tokepedia, and Shopee. MSME practitioners can also use media sharing such as YouTube, making videos with marketing content to communicate the existence of MSME products.

\section{Recommendation}

The development of industry 4.0 is the development of information technology so that we can apply marketing following technological developments so that businesses can continue to compete following the times. The lack of knowledge about information technology that entails the perpetrators of business actors in following the development 
of information technology; therefore, there is a need for training in this regard. Businesses can optimize digital marketing such as collaborative projects, for example, Wikipedia, Blogs, Content communities or media sharing, Social networking sites, Virtual social worlds, or market places.

\section{References}

Astogini, D., Wahyudin, \& Wulandari, S. Z. (2011). Aspek Religiusitas Dalam keputusan Pembelian Produk Halal (Studi tentang labelisasi halal pada produk makanan dan minuman kemasan). Jurnal JEBA, 13(1)

Wilson. J.A.J \& Liu. J, 2011, "The Challenges of Islamic branding: navigating emotions and halal", Journal of Islamic Marketing, Vol.2 No.1

Johnson, B.R et.al, 2001, Does adolescent religious commitment matter? A reexamination of the effects of religiosity on delinquency, Journal of Research in Crime and Delinquency

Imamuddin, M. (2017). Pengaruh Label Halal Dan Religiusitas Terhadap Keputusan Pembelian Mie Instan Mahasiswa IAIN Bkittinggi T.A 2016/2017. Journal of Economic Studies, 1(1),

Mukhtar, A \& Butt, M. M, 2012, "Intention to choose Halal Products: the role of of religiosity. Journal of Islamic Marketing. 3 (2): pp. 108-120.

Chaffey, D. Chadwick, F. Johnston, K. (2009). Internet Marketing: Strategy, Implementation, and Practice. Prentice Hall.
Fang, Chen Ling. Lie, T. (2006). Assessment of Internet Marketing and Competitive Strategies for Leisure Farming Industry in Taiwan. Journal of American Academy of Business, 15(May), 58. https://doi.org/10.16258/j.cnki.16745906.2006.01.022

Foroudi, P., Jin, Z., Gupta, S., Melewar, T.C. and Foroudi, M. M. (2016). Influence of innovation capability and customer experience on reputation and loyaltyJournal of Business Research. Journal of Business Research, 69.

Handaruwati, I. (2017). Pengaruh Media Sosial Terhadap Penjualan Produk Camilan Lokal Secara Online. Ekp, 13(3), 1576-1580.

Kaplan, Andreas. Haenlein, M. (2010). Users of the world unite The challenges and opportunities of Social Media. ESCP Europe, 79 Avenue de La Re' publique, F75011 Paris, France, Business Horizons, 9(1), 76-99. https://doi.org/10.1558/jsrnc.v4il.24

Kotler, P. (1997). Manajemen PemasaranEdisi Bahasa Indonesia jilid satu. Prentice Hall.

Mubarok, F. K. (2019). Optimalisasi Produk Qardhul Hasan dalam Memberdayakan Ekonomi Umat. Akuntabel, 16(1), 62-68. https://doi.org/10.29264/jakt.v16i1.463 8

Muniroh Leny, H. dan A. M. (2017). Manfaat Penggunaan Media Sosial Terhadap Peningkatan Penjualan Tas pada Pengrajin Tas Di Ciampea. Jurnal Ilmiah Inovator, September.

Pradiani Theresia. (2017). Pengaruh Sistem 
Pemasaran Digital Marketing Terhadap Peningkatan Volume Penjualan Hasil Industri Rumahan. JIBEKA, 11.

Satyo, F. (2009). Intellectual Capital. Gramedia Pustaka Utama.

Swastha, B. (2002). Manajemen Pemasaran. Liberty.

Trio Mohamad Febriyantoro, D. A. (2018). Pemanfaatan Digital Marketing Bagi Usaha Mikro, Kecil Dan Menengah Pada Era Masyarakat Ekonomi Asean. Jurnal Manajemen Dewantara, 1(September), 160-164.

Watson, D. (2006). Understanding the relationship between ICT and education means exploring innovation and change. Education and Information Technologies, 11 
Journal of Digital Marketing And Halal Industry

Vol. 2, No. I (2020) 29-42 